\title{
FMWC Radar for Breath Detection
}

Suhr, Lau Frejstrup; Tafur Monroy, Idelfonso ; Vegas Olmos, Juan José

Link to article, DOI:

10.1109/PIERS.2016.7735336

Publication date:

2016

Document Version

Publisher's PDF, also known as Version of record

Link back to DTU Orbit

Citation (APA):

Suhr, L. F., Tafur Monroy, I., \& Vegas Olmos, J. J. (2016). FMWC Radar for Breath Detection. Abstract from Progress In Electromagnetics Research Symposium 2016, Shanghai, China.

https://doi.org/10.1109/PIERS.2016.7735336

\section{General rights}

Copyright and moral rights for the publications made accessible in the public portal are retained by the authors and/or other copyright owners and it is a condition of accessing publications that users recognise and abide by the legal requirements associated with these rights.

- Users may download and print one copy of any publication from the public portal for the purpose of private study or research.

- You may not further distribute the material or use it for any profit-making activity or commercial gain

- You may freely distribute the URL identifying the publication in the public portal

If you believe that this document breaches copyright please contact us providing details, and we will remove access to the work immediately and investigate your claim. 


\title{
FMWC Radar for Breath Detection
}

\author{
L. F. Suhr, I. T. Monroy, and J. J. Vegas Olmos \\ Department of Photonics Engineering \\ Technical University of Denmark \\ Anker Engelunds vej 1, 2800 Kgs. Lyngby, Denmark
}

\begin{abstract}
We report on the experimental demonstration of an FMCW radar operating in the $25.7-26.6 \mathrm{GHz}$ range with a repetition rate of 500 sweeps per second. The radar is able to track the breathing rate of an adult human from a distance of 1 meter. The experiments have utilized a 50 second recording window to accurately track the breathing rate. The radar utilizes a saw tooth modulation format and a low latency receiver. A breath tracking radar is useful both in medical scenarios, diagnosing disorders such as sleep apnea, and for home use where the user can monitor its health.

Breathing is a central part of every human beings life as side effects from not breathing may include death. Breathing monitoring is often used in hospitals, however, the monitoring systems are usually based on physical contact with the patient. As a result, they are often a nuisance to the patient and they may even be disconnected. A better solution is contactless non-intrusive wireless measurement of the breathing.

It is found that up to $20 \%$ of the population will suffer from sleep apnea. Sleep apnea has several health related drawback. Among them are several cardiovascular outcomes, increases illness- and accident- related cost for the health system. It is hard to detect sleep apnea it is beneficial to have a sleep monitoring system in homes of people in high risk zones. However, this system would have to be unobtrusive in order for people to accept to implement them while sleeping. The only really unobtrusive way is through wireless sensing as other systems rely on either measuring the airflow at the mouth and nose through a mask or with a stretchable wire around the chest.

In this paper a wireless system that is able to measure the breath rate of a human from a distance is presented. The system is based on a commercially available radar chip which, through the use of a simple modulation scheme, is able to measure the breathing rate of an adult human from a distance. A high frequency output makes sure that the radar cannot penetrate solid obstacles which is a wanted feature in private homes where people therefore cannot measure breathing through walls.

Other remote breath tracking systems has been presented that are based on the Ultra-wideband radar technique. However, these systems have two drawbacks. Firstly, they penetrate walls. It is therefore harder to contain the emitted radiation and they could be used for unsolicited monitoring of people that are unaware of the presence of the radar. Secondly the receiver is based on timing difference between received pulses. Therefore, the receiver has to operate at a high sampling rate in the order of GSa/s to accurately track breathing rates. This high sampling rate adds unwanted complexity and power consumption to the receiver side of the radar.

This paper shows how a 25.7 - $26.6 \mathrm{GHz}$ radar can be used to track the breathing rate of a human male. Through experimental verification it is shown how the received side can be improved through digital signal processing.
\end{abstract}

\section{ACKNOWLEDGMENT}

The authors would like to thank the Villums Fonden for partly funding the research through the Villum Kann Rasmussen SEES project. 